\title{
Creating a Business Model from the Traditional to Global Fashion: Guimarẫes Embroidery
}

Fernandes, C. \& Broega, A. C.

University of Minho, Guimarães, Portugal

ABSTRACT: The great challenge of this century is the creation of new models of fashion business with sustainable principles. So, the goal of this paper is to present the process that gave rise to a set of differentiated clothing designs, through the relationship of a set of concepts more or less interconnected, which bring together sustainability principles of social and cultural, besides the environmental dimension, exploring the cultural and intangible heritage of embroidery of Guimarães. The Guimarães embroidery reflects the culture of a people and has a high potential for innovation, from both technical and aesthetic point of view, in the sense of a more contemporary reading.

\section{INTRODUCTION}

The material and immaterial cultural goods carry features of identities rooted in the culture of a people where the values are passed through generations. Most of these goods have no bibliographic records. With the interference of the culture globalization, these heritages are at risk of disappearing (Pelegrini \& Funari, 2008).

The preservation practices of material and immaterial goods contribute to the heritages to become recognized by more people, disseminating the traditions of a population, in addition they bring tourism and local economic benefits.

The hand embroideries is one of those tangible and intangible heritage that testify the culture of a people, according to Guimarães Embroidery book coordinated by Isabel Fernandes, it is about those that is devoted this work, in which is wanted to value it in a more contemporary way, as well as highlight the work of those who make it.

Another aspect that this work will take into account is the socio-cultural sustainability in a perspective of preserving the culture, but also environmental sustainability devaluing consumerism and giving strength to the idea of acquiring durable and timeless products.

The work aims to transform the traditional to a more contemporary dimension exploring different materials, colours and designs.

\section{THEORETICAL FRAMEWORK}

\subsection{Design Problem}

The Cultural Sustainability aims to recognize and consider the diversity of customs and traditions of a people, but in a globalized world these traditions tend to be ignored or banalized (Dessein \& Battaglini \& Horlings 2016). The embroidery from Guimarães is a traditional (handicraft) art that come from the ancestors of a small town full of history and like any other art should be promoted in order to avoid losing it.

One way to make the product (Guimarães typical embroidery) prevail and even be recognized globally is attempt to innovate it without its decharacterization. In this case to make it contemporary, with the creation of a new line of products not yet exploited by this type of embroidery was the approach of this project.

For the product to do not lose its identity, there are conditions to be respected, either in the generation of innovation in product or in its way of manufacturing. However respecting the embroidery identity conditions, there is the possibility to explore new raw materials and/or colours (of materials or yarns) to keep up with the current markets trends and fashion. It also allows the creation of new designs as long as they are stylized and geometrized. For those products could be considered contemporary and accepted by the Monitoring Committee ${ }^{1}$, one can only change one-variation from conditions established at a time.

Objectives

- This work is part of a research master's degree studying the Guimarães of manual embroideries from the point of view of its tangible and intangible value. Aims to explore the potential of Guimarães embroidery in a more technical sense (material value) in order to a more contemporary application of the traditional knowledge;

- The main objective is conceive fashion design products materializing Guimarães embroidery, in a sense of enhancement of cultural and social sustainability.

\subsection{Cultural Sustainability}

Preserving the culture of a region involves the valorisation of what is authentic, which is pictur-

\footnotetext{
${ }^{1}$ Text prepared by the Alberto Sampaio Museum Team who accompanied the research of Guimarães embroidery, with a view to its official certification of the product.
} 
esque and typical for the recovery of an ethnographic perspective (Lóssio \& Pereira, 2007). The cultural heritage can contribute to strengthen of the right to existence of cultural diversity, promoting intercultural dialogue, enable communities to benefit from development and social and economic profitability (Sousa, 2015).

Over the centuries all-important discoveries were staying and contributing to the cultural and material development of man. Industrialization can bring many benefits to humanity, but on the other hand can cause the craftwork fall in a complete contempt, or that some traditional knowledge manuals such as embroidery namely of "sweetheart handkerchiefs ${ }^{2}$ " which began to be printed indiscriminately in various articles, whether fabric, ceramic or other, which led to the loss of its cultural and traditional value.

\subsection{Embroidery of Guimarães}

These days the Guimarães embroidery has well defined characteristics: the drawings, the materials, the variety of stitch to be used, the colours used alone or combined and even the quality/perfection of the embroidery execution, as the all design, however, it was not always like this. Currently we have a embroidery which is adjusted the accuracy and Certification, with a historical root divided into four phases: "Antecedents", "Popular Embroidery of Guimarães", and finally, "Embroidery of Guimarães: Renaissance and Consolidation". In the first phase, running from the $19^{\text {th }}$ century and beginning of the $20^{\text {th }}$ century, there is no reference to the designation of "Embroidery of Guimarães", are rather references to " Rich Embroidery "3, the floral motifs and monograms embroidery. The second phase, running from the end of the $19^{\text {th }}$ century and $20^{\text {th }}$ century, deals with the exploitation of embroidery by the popular classes because, previously only was explored by higher social classes. The third phase is the beginning of the growth of an identity by the Vimaranense $^{4}$ embroidery, with those gaining its own characteristics, that make it different from other embroidery and which are still considered mandatory. Finally, the revival and consolidation that demonstrates the need to preserve the legacy of Vimaranense ancestors allowing embroidery to reborn and take new contours: characteristics defined in materials, in embroidery designs, in the accuracy

\footnotetext{
${ }^{2}$ Sweetheart handkerchiefs: is a traditional hand embroidered handkerchief, full of symbolic values, which traditionally are embroidered in northern Portugal, in the Minho region, so called the "Lenço dos Namorados". http://aliancartesanal.pt/site/home.asp?pagina=s

3 [Bordado Rico]-Embroidery in white perfect and elegant, revealing a skill and dexterity, only possible by delicate female hands accustomed to do so (Fernandes, 2006).

4 Relative or belonging to Guimarães or from the city of Guimarães, birthplace of Portuguese nationality.
}

of the designs and technology, and in its own market which is intended to be extended (Fernandes, 2006).

Traditionally, what characterizes this embroidery is the great relief, the great diversity of stitchs that are combined in the same piece, and have a design always symmetric (the nature geometrized or stylized). The embroidery designs are applied on fabrics with the help of basting stitches and needle using certain types of stitches. In the case of embroidery of Guimarães, there are twenty-one different types of stitches, which may be used and combined. It is the stitches "canutilho" the considered obligatory (figure 1). Through different stitches with the same design, it is possible to obtain completely different effects but also spectacular. The yarn colours traditionally used in embroidery are: blue, beige, white, gray, red and black. Although embroidery is characterized by the use of these colours, each embroidery is monochromatic, in each piece cannot be more than one colour yearn embroidery (Fernandes, 2006).

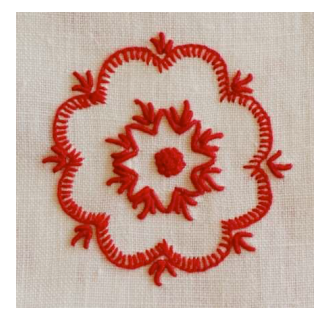

Figure 1: Stitche "canutilho" (Bordados de Guimarães, 2006)

Embroidery of Guimarães has been transformed over time and acquired a set of features that guarantee it singularity. In the middle ages the craftsmen worked with precious materials such as silver, gold and even precious stones meting in this way the whims of the elements of royalty and clergy. Embroidering has always been an art of high economic cost, so that the people would not have afforded the embroidered goods. "Thanks to the fact that the clergy and royalty were so capricious, having very peculiar and refined tastes, there was a great development of embroidery at that time. However, the luxuries pay is expensive and after a few decades, some monarchs started to create "pragmatic", i.e. laws against exaggeration of luxury. Consequently there was a decline in the embroidery, in both technically and in the design" (Fernandes, 2006).

Embroidering was not considered a profession but a way for women of high society spending time. It was an activity that was part of female education. But that art would eventually be learned by the lowstatus women, because they were maids and helped in times where patience and dedication was needed to spinning, weaving, sewing, embroidery (Fernandes, 2006).

It is very little the literature on the embroidery of Guimarães, and few are the records of parts or documentation related to this embroidery especially before the $19^{\text {th }}$ century, however, thanks to a partner- 
ship between the "Oficina" and Alberto Sampaio Museum, and the collaboration of some people who offered their embroidery pieces, a book was published and it gives access to all relevant details and some story's as well as illustrations of various types of stitches.

Some of the pieces that consecrated the mentioned embroidery were the farmer's shirt used only in feasts days and in many cases accompanied its owner to the grave. Belonging to popular costume, which is registered as a part of the end of the $21^{\text {st }}$ century, is the female "tails waistcoat", (Figure 2. Colete de Rabos) quite decorated, and little is known about its origin.

The "sweetheart handkerchiefs" are also exploited by this embroidery. It is one piece which was repeatedly embroidered by their symbolism ${ }^{5}$ and because it is less expensive because of their small size.

At the beginning of the 20th century began to be exploited as home textile pieces like bed sheets and pillow and in the decades 40-60 ladies from high society decorated with Guimarães embroidery only at the cottages houses (Fernandes, 2006).

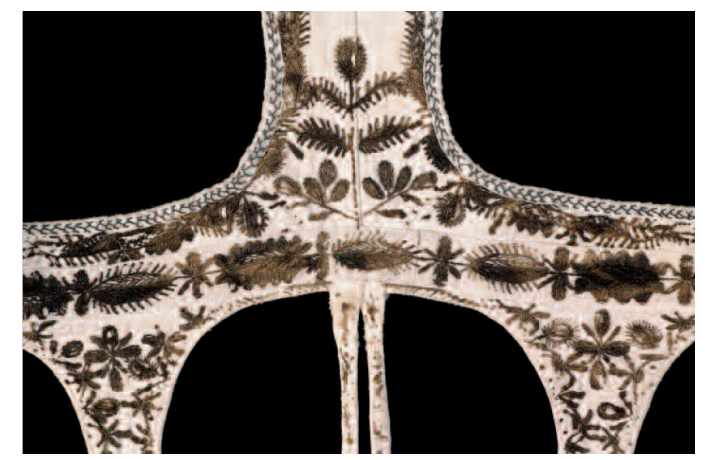

Figure 2 Female tails waistcoat (Bordados de Guimarães, 2006)

\subsection{Market Research}

The Guimarães embroidery's are still very geared to the home textiles, very dedicated, traditional and high quality. The infrastructure that currently exist as sales point of embroidered products of Guimarães are shops that are located in the Historic Center of Guimarães ${ }^{6}$ and they all sell products related to the home textiles and a few accessories.

The wedding dresses have also been exploited in the past, but now, as the embroidery is very labourintensive, and therefore makes the product very expensive, have become less popular.

\footnotetext{
5 Symbolically represented that if a girl was interested in a young man would offer him an embroidered handkerchief made by her, and if he accepted, he would take it on his neck to the church the following Sunday and meant that both assumed a dating commitment.

${ }^{6}$ It has its Regional Embroidery Craft Centre studio on "OCICINA": Arts Centre and Mesteres Traditional Guimarães" in Street da Rainha, in Guimarães City, Portugal.
}

At the level of fashion designers that explore this embroidery, records are not found. The own embroiderers from de "Oficina Space" testify to "the lack of involvement or request for cooperation from interested designer to work embroidery in their design products."

Industrially, it has long been trying to imitate the handmade embroidery and in some cases with an incredibly similar effect. In the home-textile sector the Guimarães embroidery was no exception as to the industrial reproduction (figure 3), although the difficulty is greater than other types of embroidery due to the enormous amount of different types of characteristic stitches.

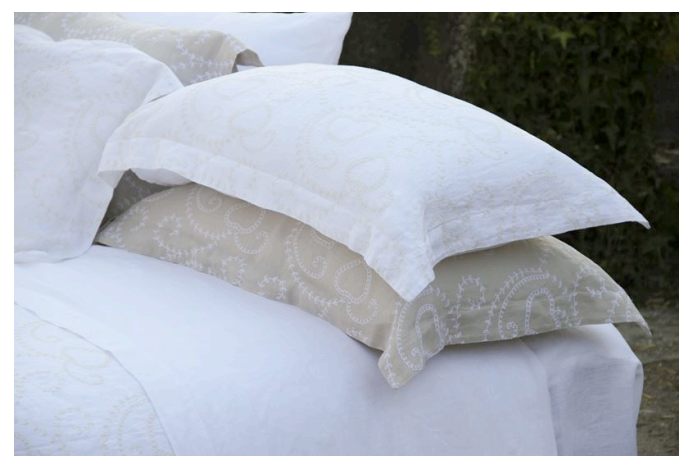

Figure 3: Sheet bedding set inspired by the embroidery of Guimarães

There are recent records of ceramic pieces, tiles and printed fabrics inspired with designs from the embroideries of Guimarães (figure 2)

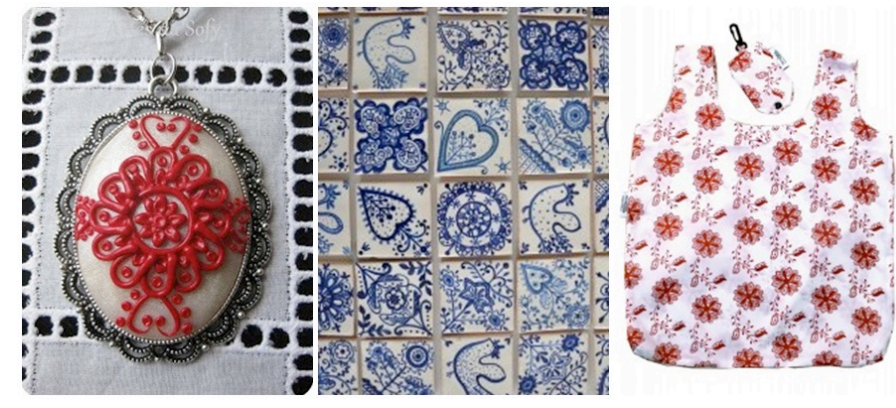

Figure 4: Fashion accessories ${ }^{8}$; Tiles, ${ }^{9}$ and Printed Fabric Bag ${ }^{10}$

\section{CREATING NEW PRODUCT}

\subsection{The development of differentiated product}

The methodology approach of this project is based on the design thinking from Brow (2008) summarized in three phases: the inspiration, that

\footnotetext{
7 http://www.amaliahomecollection.com/product/coracao

8 http://artesdasofy.blogspot.pt/2012/06/bijuteriainspirada-nastradicoes.html

9 Azulejos http://www.projectoa2.com/prja2/

10 http://www.hipersuper.pt/2015/04/13/terra-lusa-lanca-sacos-de-
}

compra-reutilizaveis-inspirados-na-cultura-portuguesa/ 
identifies the real problem; ideation, which is the process of creating ideas to generate innovations that solves the underlying problem and occurs the selection of the best(s) idea(s) and implementation, which as the name itself implies is the implementation of the solution(s) idealized.

This article presents the results of the firsts phases, the inspiration and ideation starting with an exploratory research through observation, interviewing and literature revision.

The potential of the Guimarães embroidery is enormous, and the possibilities for innovation increases progressively when assign it new concepts. One of the concepts taken into account throughout this project is sustainability. Despite having valued the cultural, technical and innovative aspect of the embroidery and the social side that values the experience and coexistence of human beings, the pillar of sustainability, that has been the society major concern of, which is the environment, is also treated in the project. So this includes the creation of products with a sustainable concept from its origins with features such as: natural raw materials (wool and its mixes), although different from those traditionally employed (cotton and linen), yet regional manufacturing preference (the local artisans); uses a zerowaste modelling principles (the minimization of wastes), with one-fits all concept (In the sense of dress more biotypes); valuing the fair-trade of manuality and local culture.

The project was inspired to one of the most emblematic pieces of the traditional history of embroidery of Guimarães, the lady "tails waistcoat", which resulted in the creation of a mini collection of structurally different and innovative waistcoats, materializing the Guimarães embroidery in a piece of design, which can be used in numerous occasions. It is outerwear garments that require low maintenance and conservation. Each piece tells a story, promoting the desire to preserve and share the wealth of what is genuine and traditional.

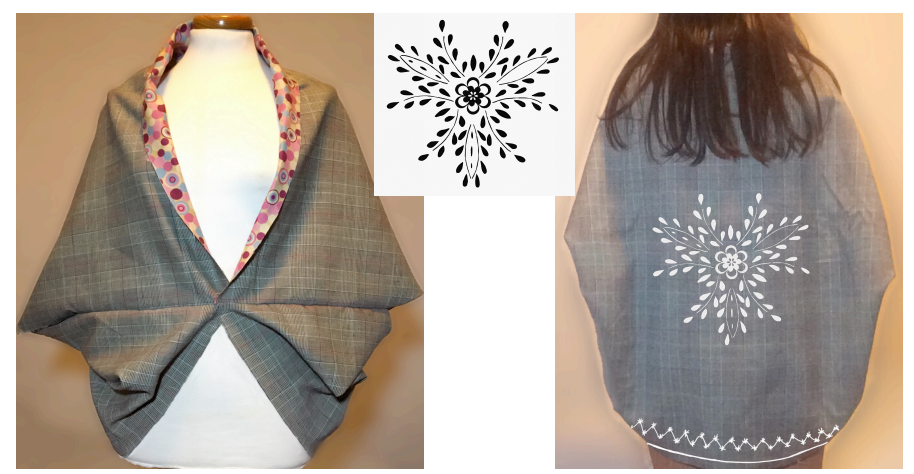

Figure 5: One of the idealised product (In wool mixes material, zero-waste modelling principles, zero-waste modelling principles, nature geometrized embroidery design, with "canutilho" stitches' in a monochromatic style).

In the figure 5 we present one of the idealised product, but in this article we are not allowed to pre- sent the full range of final products developed because they are in a certification process at the time of this publication, so it is planning to present the collection very soon.

\subsection{The product marketing (perspectives)}

The proposal is, with these products to create a new Portuguese Brand of clothing with Design, which is assumed unique, authentic and with strong regional/national identity, able to conquer an informed public, passionate and conscious that values authentic in modern, functional and durable clothing, pieces arousing emotions and desire. It is intended to be a brand of exclusive pieces, timeless, perpetual and worthy of being left in inheritance. The business model will be online sales through an Internet site so it can be appreciated and purchased globally.

\section{CONCLUSION}

This work was born from the will of a young designer born in from the Guimarães region who used her master degree dissertation project in Design and Marketing to develop this study and create fashion design products focusing on sustainability, not only environmental but mainly social and cultural. Aims to explore the local and traditional culture of Guimarães embroidery involving the knowledge and

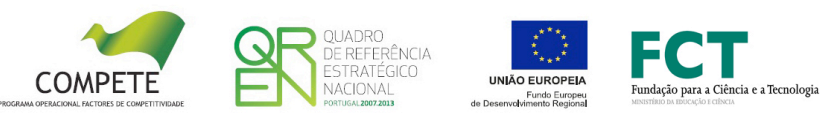

local skilled crafts in the development of new contemporary design products.

Identified the business opportunity and made the prototypes, future prospective of this work, goes for developing a business model based on the principles of sustainability and co-design.

\section{ACKNOWLEDGEMENTS}

"This work is supported by FEDER funds through the Competitivity Factors Operational Programme COMPETE and by national funds through FCT Foundation for Science and Technology within the scope of the project POCI-01-0145-FEDER007136"

\section{REFERENCES}

Brown, T. 2008. Design Thinking. Obtained from: http://www.ideo.com/images/uploads/news/p dfs/IDEO HBR Design_Thinking.pdf. 
Dessein, J., \& Battaglini, E., \& Horlings, L. (2016). Cultural Sustainability and Regional Development -Theories and practices of territorialisation. Routledge.

Fernandes, I. M. (2006). Bordados de Guimarães. Campo das Letras.

Lóssio, R. A., \& Pereira, C. d. (Maio de 2007). Obtido de A IMPORTÂNCIA DA VALORIZAÇ̃̃O DA CULTURA POPULAR PARA O DESENVOLVIMENTO LOCAL: http://www.cult.ufba.br/enecult2007/RubiaRi beiroLossio_CesardeMendoncaPereira.pdf

Oficina. (s.d.). Bordado de Guimarães - Caderno de Especificações.

Pelegrini, S. C., \& Funari, P. P. (2008). O que é o Património Imaterial. Brasilense.

Sousa, F. (2015). Património Cultural e Imaterial. MEMORIAMEDIA e-Museu - métodos, técnicas e práticas. Memória Imaterial CRL. 